\title{
4-ETOKSI-3-METOKSIFENOL DAN METIL-3,4-DIHIDROKSIBENZOAT, DUA SENYAWA TURUNAN FENOLIK DARI EKSTRAK ETIL ASETAT KULIT UMBI GADUNG (Dioscorea hispida Dennst) DAN AKTIVITAS ANTIOKSIDAN EKSTRAK ETIL ASETAT
}

\author{
Nanik Siti Aminah ${ }^{1 *}$, Alfinda Novi Kristanti ${ }^{1}$, Qonitah Labibah ${ }^{2}$, \\ Ana Firdausiyah ${ }^{3}$, Yoshiaki Takaya ${ }^{4}$ \\ ${ }^{1}$ Departemen Kimia, Fakultas Sains dan Teknologi \\ Universitas Airlangga \\ ${ }^{2}$ Mahasiswa Magister Kimia, Departemen Kimia, Fakultas Sains dan Teknologi \\ Universitas Airlangga \\ ${ }^{3}$ Mahasiswa S-1 Kimia, Departemen Kimia, Fakultas Sains dan Teknologi \\ Universitas Airlangga \\ ${ }^{4}$ Faculty of Pharmacy, \\ Meijo University \\ ${ }^{8}$ email: nanik-s-a@fst.unair.ac.id
}

Received 1 April 2018

Accepted 2 Mei 2018

\begin{abstract}
Two phenolic compound namely 4-ethoxy-3-methoxyphenol and methyl-3,4dihydroxybenzoic have been isolated from Dioscorea hispida Dennst. The isolation of phenolic compounds was done by maceration methods using methanol, followed by partition with n-hexane and ethyl acetate. The process of separation and purification used various chromatography techniques including vacuum liquid chromatography, column chromatography, and radial chromatography. The structure of isolated compounds were determined by spectroscopic methods including UV-Vis, IR, 1D and 2D NMR. The ethyl acetate extract was evaluated for DPPH free radical scavenging activity assay. The $\mathrm{IC}_{50}$ of ethyl acetate extract was $415 \mathrm{ppm}$. The result of this assay indicated that ethyl acetate extract has a potential as an antioxidant.
\end{abstract}

Keywords: Dioscorea hispida Dennst, Dioscoreaceae, phenolic, 4-ethoxy-3methoxyphenol, methyl-3,4-dihydroxybenzoic, and antioxidant

\section{Pendahuluan}

Radikal bebas berupa molekul atau senyawa yang mengandung satu atau lebih elektron tidak berpasangan. Hal inilah yang menyebabkan radikal bebas bersifat tidak stabil. Agar stabil maka radikal bebas mencoba untuk menarik ataupun memberikan elektron yang dimilikinya ke molekul lain. Ketika radikal bebas menyerang suatu molekul maka molekul yang awalnya netral akan berubah menjadi radikal. Proses ini dapat menyebabkan reaksi berantai yang mengakibatkan kerusakan pada sel seperti penyakit hati dan jantung, penurunan kemampuan kognitif, atau bahkan kanker (Kothari et al., 2010).

Radikal bebas yang merusak tubuh dapat dinetralisir dengan menggunakan senyawa antioksidan. Antioksidan memiliki kemampuan untuk menetralisir radikal bebas tanpa menjadi radikal bebas itu sendiri. Ketika antioksidan menetralkan radikal bebas dengan menerima atau menyumbangkan elektron, antioksidan akan tetap stabil dan tidak akan berubah menjadi radikal bebas. Dengan kata lain, antioksidan menawarkan elektronnya untuk mencegah kerusakan sel (Middleton et al., 1998). Tubuh manusia 
sebenarnya menghasilkan senyawa antioksidan sebagai sistem pertahanan diri. Sayangnya tubuh manusia tidak mempunyai cadangan antioksidan berlebih sehingga jika terjadi paparan radikal bebas maka tubuh akan membutuhkan asupan antioksi dan dari luar (Sunarni et al., 2005).

Salah satu tumbuhan di Indonesia yang berpotensi untuk dikembangkan sebagai sumber antioksidan alami yaitu umbi gadung (Dioscorea hispida Dennst). Tanaman gadung (Dioscorea hispida Dennst) dari famili Dioscoreaceae merupakan salah satu dari sekian banyak tanaman pangan yang ada di Indonesia. Umbi ini sudah tak asing lagi di kalangan masyarakat. Berdasarkan studi literatur, terdapat sebanyak 4 senyawa fenolik yang telah berhasil diisolasi diantaranya, asam klorogenat, metil protokatekuat, asam kafeat, dan $p$-hidroksibenzaldehid (Theerasin et al., 2009). Senyawa-senyawa fenolik dari genus Dioscorea menunjukkan berbagai bioaktivitas seperti antioksidan, antiinflamasi, antitoksik, dan antikanker (Chiu et al., 2013; Min et al., 2011; Itharat etl al., 2014). Namun penelitian mengenai aktivitas antioksidan dari Dioscorea hispida Dennst masih sangat terbatas.

Penelitian ini bertujuan untuk mengisolasi dan mengidentifikasi struktur senyawa fenolik pada ekstrak etil asetat kulit umbi gadung (Dioscorea hispida Dennst). Proses penelitian diawali dengan tahap maserasi menggunakan pelarut metanol untuk mengekstrak senyawa metabolit sekunder dari kulit umbi Dioscorea hispida Dennst. Selanjutnya dilakukan metode ekstraksi cair-cair terhadap ekstrak metanol yang diperoleh dengan menggunakan $n$-heksana diikuti etil asetat dan dilanjutkan dengan pemisahan serta pemurnian senyawa fenolik dengan menggunakan berbagai teknik kromatografi. Setelah diperoleh senyawa murni maka selanjutnya dilakukan penentuan struktur senyawa fenolik menggunakan metode spektroskopi yang meliputi UV-Vis, IR, 1D dan 2D NMR.

Pada penelitian ini juga dilakukan uji aktivitas antioksidan ekstrak etil asetat kulit umbi Dioscorea hispida Dennst menggunakan metode spektroskopi UVVis dengan pereaksi DPPH (1,1-difenil-1pikrilhidrazil) (Koleva et al., 2002). Metode ini memberikan informasi mengenai reaktivitas peredaman radikal bebas DPPH oleh sampel yang diuji. DPPH memberikan serapan kuat pada panjang gelombang $517 \mathrm{~nm}$ dengan warna ungu gelap. Peredaman radikal bebas DPPH menyebabkan terbentuknya perubahan warna dari ungu tua menjadi kuning terang (Sasikumar et al., 2009).

\section{Metode Penelitian}

Alat dan bahan

Sampel yang digunakan dalam penelitian ini adalah kulit umbi gadung (Dioscorea hispida Dennst) yang berasal dari Desa Besuki, Kecamatan Besuki, Kabupaten Tulungagung, Provinsi Jawa Timur. Bahan kimia yang digunakan adalah $\mathrm{MeOH}$, EtOAc, $n$-heksana, $\mathrm{CHCl}_{3}$, aseton, silika gel $60 \mathrm{GF}_{254}$ ukuran $0.25 \mathrm{~mm}$ (Merck), silika gel G-60 ukuran 60-200 $\mu \mathrm{m}$, silika gel 60 ukuran $0.200-0.500 \mathrm{~mm}$ (Merck 7733), silika gel $60 \mathrm{PF}_{254}$ (Merck 7749), pereaksi DPPH (1,1-difenil-1-pikril hidrazil), natrium asetat, asam asetat glasial, asam askorbat dan aquades.

Peralatan yang digunakan meliputi bejana maserasi, corong pisah, chamber, lampu UV, kolom kromatografi, pHmeter, rotary vacum evaporator, kromatotron, dan seperangkat alat destilasi. Untuk keperluan analisis dan identifikasi senyawa digunakan spektrofotometer UV-Vis Shimadzu 1800, spektrofotometer FT-IR Shimadzu Tracer100, dan spektrofotometer NMR BRUKER $600 \mathrm{MHz}$.

\section{Prosedur \\ Isolasi senyawa fenolik}

Isolasi senyawa fenolik dari kulit umbi Dioscorea hispida Dennst $(2,5 \quad \mathrm{~kg})$ 
dilakukan dengan metode ekstraksi padatcair dengan cara maserasi pada suhu kamar. Ekstraksi ini dilakukan sebanyak tiga kali menggunakan pelarut $\mathrm{MeOH}$. Filtrat kemudian dipisahkan dari pelarutnya dan dipekatkan dengan menggunakan rotary vacum evaporator hingga diperoleh ekstrak kental $\mathrm{MeOH}$ sebesar 243 g (9,72\%) . Ekstrak kental $\mathrm{MeOH}$ yang telah diperoleh diekstraksi cair-cair menggunakan pelarut $n$-heksana untuk menghilangkan kandungan lemak dan senyawa-senyawa non polar lainnya yang dapat mengganggu proses pemisahan senyawa fenolik. Hasil dari partisi yaitu terbentuknya dua lapisan, yakni lapisan atas berupa fraksi $\quad n$-heksana dan lapisan bawah berupa fraksi $\mathrm{MeOH}$. Ekstrak $n$-heksana yang didapat diuapkan dengan menggunakan rotary vacum evaporator hingga diperoleh ekstrak kental $n$-heksana yang berwarna cokelat sebanyak $16 \mathrm{~g}(0,64 \%)$. Ekstrak metanol yang didapatkan ditambah dengan EtOAc dan air. Partisi ini menghasilkan dua lapisan, yakni lapisan atas berupa ekstrak EtOAc dan lapisan bawah berupa ekstrak $\mathrm{MeOH}$. Ekstrak EtOAc yang didapat diuapkan dengan menggunakan rotary vacum evaporator hingga diperoleh ekstrak kental EtOAc yang berwarna cokelat kehitaman sebanyak $17 \mathrm{~g}(0,68 \%)$.

Pemisahan senyawa fenolik yang terdapat dalam ekstrak EtOAc (17 g) diawali dengan kromatografi cair vakum menggunakan eluen $n$-heksana: EtOAc yang kepolarannya ditingkatkan secara gradien menghasilkan enam fraksi utama yaitu A-F.

Pemisahan fraksi D $(560 \mathrm{mg})$ dilakukan dengan kromatografi kolom gravitasi menggunakan eluen $n$-heksana:EtOAc $=$ $(9: 1), \quad(8: 2), \quad(7: 3), \quad(3: 2), \quad(1: 1)$ menghasilkan subfraksi $\mathrm{D}_{1}-\mathrm{D}_{5}$.

Pemurnian pada sub-fraksi D $D_{5} \quad(274$ mg) dilakukan dengan kromatografi radial menggunakan eluen $n$-heksana:EtOAc $=$ $(1: 1), \quad(4: 6), \quad(3: 7), \quad(2: 8), \quad(1: 9)$ menghasilkan tiga sub-fraksi yaitu $\mathrm{D}_{5.1^{-}}$ D5.5. Sub-fraksi $\mathrm{D}_{5.3}$ menghasilkan spot dengan noda tunggal sehingga didapatkan senyawa fenolik (1) sebanyak $2 \mathrm{mg}$ yang berwujud padatan berwarna kuning. Uji kemurnian senyawa fenolik (1) dilakukan dengan analisis KLT menggunakan tiga sistem eluen yang berbeda. Eluen yang digunakan yaitu $\mathrm{CHCl}_{3}$ : aseton $(9: 1)$ $(\mathrm{Rf}=0,47), \mathrm{CHCl}_{3}:$ EtOAc $(1: 1)(\mathrm{Rf}=0,5)$, serta $n$-heksana:aseton $(8: 2)(\mathrm{Rf}=0,4)$.

Sub-fraksi $\mathrm{D}_{5.5}(56,4 \mathrm{mg})$ dimurnikan dengan kromatografi radial menggunakan eluen $\mathrm{CHCl}_{3}$ :EtOAc menghasilkan enam sub-fraksi yaitu $\quad \mathrm{D}_{5.51}-\mathrm{D}_{5.56}$. Sub-fraksi $\mathrm{D}_{5.55}$ dan $\mathrm{D}_{5.56}$ digabung karena menghasilkan spot sama. Sub-fraksi ini menghasilkan spot dengan noda tunggal sehingga didapatkan senyawa fenolik (2) sebanyak 34,1 mg yang berwujud padatan berwarna kuning cerah. Uji kemurnian senyawa fenolik (2) dilakukan dengan analisis KLT menggunakan tiga sistem eluen yang berbeda. Eluen yang digunakan yaitu $\mathrm{CHCl}_{3} 100 \%$ ( $\left.\mathrm{Rf}=0,57\right), \mathrm{CHCl}_{3}$ : EtOAc (9:1) $(\mathrm{Rf}=0,85)$, serta $n$-heksana: EtOAc $(8: 2)(\mathrm{Rf}=0,23)$.

\section{Uji aktivitas antioksidan}

Uji aktivitas antioksidan ekstrak etil asetat kulit umbi Dioscorea hispida Dennst dilakukan menggunakan metode spektroskopi UV-Vis dengan pereaksi DPPH (1,1-difenil-1-pikrilhidrazil).

Pada uji ini digunakan asam askorbat sebagai kontrol positif dan ekstrak etil asetat kulit umbi Dioscorea hispida Dennst sebagai sampel. Sebanyak $500 \mu \mathrm{L}$ larutan uji variasi konsentrasi $(10,25,50$, 125, 250, dan 500 ppm) ditambahkan dengan $500 \mu \mathrm{L}$ larutan buffer asetat $0,2 \mathrm{M}$ (pH 5,5), $1000 \mu \mathrm{L}$ metanol, dan $500 \mu \mathrm{L}$ larutan DPPH $5 \times 10^{-4} \mathrm{M}$. Larutan uji diinkubasi dalam ruang gelap selama 30 menit. Selanjutnya larutan uji diukur absorbansinya pada $\lambda_{\text {maks }} 517 \mathrm{~nm}$. Data absorbansi yang diperoleh dianalisis untuk menentukan daya hambat sesuai persamaan 1 dengan $A_{0}$ merupakan absorbansi blanko dan $A_{1}$ merupakan absorbansi sampel ataupun kontrol positif. 
Pengukuran absorbansi dilakukan secara duplo dan hasilnya dirata-ratakan.

$$
\text { DPPH }(\%)=\frac{\left(A_{0}-A_{1}\right) \times 100}{A_{0}}
$$

Analisis data mengenai daya hambat inhibitory concentration $\left(\mathrm{IC}_{50}\right)$ ditentukan berdasarkan analisis regresi linier \% peredaman DPPH terhadap konsentrasi senyawa. Nilai $\mathrm{IC}_{50}$ menyatakan besarnya konsentrasi sampel yang dibutuhkan untuk mengurangi sebesar 50\% radikal DPPH $[10,11]$.

\section{Hasil dan Pembahasan}

Senyawa fenolik (1) berwujud padatan berwarna kuning. UV $(\mathrm{MeOH}) \lambda_{\text {maks }}(\log$ ع): 260 (4,05). IR (KBr) vmaks 3385, $2924,2850,1516,1271 \mathrm{~cm}^{-1}$. Spektrum ${ }^{13} \mathrm{C}$ NMR yang dilengkapi dengan DEPT 90 dan DEPT 135 memperlihatkan adanya 9 sinyal karbon yang terdiri dari dua sinyal karbon metil $\left(\delta_{\mathrm{C}} 29,6\right.$ dan 55,9 ppm), tiga sinyal karbon metin $\left(\delta_{\mathrm{C}} 118,5 ; 108,5\right.$ dan $114,2 \mathrm{ppm})$, satu sinyal karbon metilen $\left(\delta_{\mathrm{C}}\right.$ $56,3)$, serta tiga sinyal karbon kuarterner $\left(\delta_{\mathrm{C}} 145,2 ; 146,7\right.$ dan $\left.135,0 \mathrm{ppm}\right)$.

Spektrum ${ }^{1} \mathrm{H}-\mathrm{NMR} \quad(600 \mathrm{MHz}$, $\mathrm{CDCl}_{3}$ ) memperlihatkan adanya tiga sinyal proton aromatik, yaitu sinyal double doublet pada $\delta_{\mathrm{H}} 6,84 \mathrm{ppm}$ dengan kopling orto $(J=7,8 \mathrm{~Hz})$ dan meta $(J=1,8 \mathrm{~Hz})$ terhadap proton aromatik lainnya. Kedua proton aromatik lainnya merupakan sinyal doublet pada $\delta_{\mathrm{H}} 6,92$ dan 6,91 ppm. Sinyal tersebut menandakan adanya tiga proton aromatik dan terikat pada cincin benzena. Sinyal proton lainnya memperlihatkan adanya sinyal quartet $\left(\delta_{\mathrm{H}} 4,14 \mathrm{ppm}\right)$ serta sinyal triplet $\left(\delta_{\mathrm{H}} 1,28 \mathrm{ppm}\right)$ yang menandakan adanya subtituen etil. Selain itu, spektrum ${ }^{1} \mathrm{H}-\mathrm{NMR}$ juga memperlihatkan sinyal singlet gugus metoksi $\left(\delta_{\mathrm{H}} 3,93 \mathrm{ppm}\right)$ dan sinyal singlet gugus hidroksi $\left(\delta_{\mathrm{H}} 5,59 \mathrm{ppm}\right)$.

Spektrum HSQC merupakan korelasi antara sinyal proton dari ${ }^{1} \mathrm{H}$ NMR dengan sinyal karbon dari ${ }^{13} \mathrm{C}$ NMR dalam satu ikatan. Analisis spektrum
HSQC memperlihatkan enam korelasi sinyal proton dengan sinyal karbon dalam satu ikatan, diantaranya : proton pada $\delta_{\mathrm{H}}$ $6,84 \mathrm{ppm}$ berkorelasi dengan karbon $\delta_{\mathrm{C}}$ $118,5 \mathrm{ppm}$, proton pada $\delta_{\mathrm{H}} 6,92 \mathrm{ppm}$ berkorelasi dengan karbon $\delta_{\mathrm{C}} 108,5 \mathrm{ppm}$, proton pada $\delta_{\mathrm{H}} 6,91 \mathrm{ppm}$ berkorelasi dengan karbon $\delta_{\mathrm{C}} 114,2 \mathrm{ppm}$, proton pada $\delta_{\mathrm{H}} 1,28 \mathrm{ppm}$ berkorelasi dengan karbon $\delta_{\mathrm{C}}$ 29,6 ppm, proton pada $\delta_{\mathrm{H}} 4,14 \mathrm{ppm}$ berkorelasi dengan karbon $\delta_{\mathrm{C}} 56,3 \mathrm{ppm}$, dan proton pada $\delta_{\mathrm{H}} 3,93 \mathrm{ppm}$ berkorelasi dengan karbon $\delta_{\mathrm{C}} 55,9 \mathrm{ppm}$.

Spektrum HMBC merupakan korelasi antara sinyal proton dari ${ }^{1} \mathrm{H}-$ NMR dengan sinyal karbon dari ${ }^{13} \mathrm{C}$ NMR dalam dua atau tiga ikatan. Dalam hal ini hasil analisisnya dapat digunakan untuk menempatkan posisi subtituen. Korelasi HMBC digambarkan seperti pada Gambar 1. Berdasarkan data spektrum ${ }^{13} \mathrm{C}-\mathrm{NMR},{ }^{1} \mathrm{H}-\mathrm{NMR}$, HSQC, dan HMBC maka struktur senyawa fenolik (1) diprediksi sebagai senyawa fenol yang dikenal dengan nama 4-etoksi-3metoksifenol . Analisis 1D dan 2D NMR untuk senyawa 4-etoksi-3-metoksifenol terdapat pada Tabel 1.

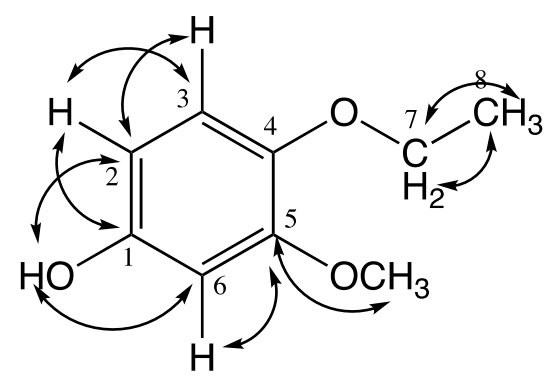

Gambar 1. Struktur senyawa 4-etoksi-5 metoksifenol hasil isolasi

Senyawa fenolik (2) berwujud padatan berwarna kuning cerah. UV $(\mathrm{MeOH}) \lambda_{\text {maks }}$ $(\log \varepsilon)$ : $256(4,05)$ dan 292,2 (4,05). Spektrum ${ }^{13} \mathrm{C}$-NMR yang dileng-kapi dengan DEPT 90 dan DEPT 135 memperlihatkan adanya 8 sinyal karbon yang terdiri dari satu sinyal karbon metil $\left(\delta_{\mathrm{C}} 47,8 \mathrm{ppm}\right)$, tiga sinyal karbon metin $\left(\delta_{\mathrm{C}}\right.$ 114,$4 ; 116,4$ dan 122,3 ppm), serta empat 
sinyal karbon kuarterner $\left(\delta_{\mathrm{C}} 122,9 ; 144,4\right.$; 149,7; dan 169,6 ppm.

Spektrum ${ }^{1} \mathrm{H}-\mathrm{NMR}(600 \mathrm{MHz}, \mathrm{MeOH})$ memperlihatkan adanya tiga sinyal proton di daerah aromatik, yaitu sinyal double doublet pada $\delta_{\mathrm{H}} 7,45 \mathrm{ppm}$ dengan kopling orto $(J=8,22 \mathrm{~Hz})$ dan meta $(J=2,04 \mathrm{~Hz})$ terhadap proton aromatik lainnya. Kedua proton aromatik lainnya merupakan sinyal doublet pada $\delta_{\mathrm{H}} 6,80$ dan 7,43 ppm. Sinyal tersebut menandakan adanya tiga proton aromatik dan terikat pada cincin benzena. Sinyal proton lainnya memperlihatkan adanya sinyal singlet gugus metoksi $\left(\delta_{\mathrm{H}}\right.$ 3,33 ppm).

Tabel 1 Data NMR senyawa 4-etoksi-3-metoksifenol hasil isolasi dari kulit umbi Dioscorea hispida Dennst $\left(600 \mathrm{MHz}, \mathrm{CDCl}_{3}\right)$

\begin{tabular}{cccc}
\hline $\mathrm{C}$ & $\delta_{\mathrm{H}}(\mathrm{ppm})($ mult,$J$ dalam Hz$), \mathrm{I}$ & $\delta_{\mathrm{C}}(\mathrm{ppm})$ & $\mathrm{HMBC}$ \\
\hline 1 & - & 145,2 & - \\
2 & $6,84(d d, J=1,8$ dan $7,8 \mathrm{~Hz}), 2 \mathrm{H}$ & 118,5 & $\mathrm{C}-1, \mathrm{C}-3$ \\
3 & $6,92(d, J=8,4 \mathrm{~Hz}), 2 \mathrm{H}$ & 108,5 & $\mathrm{C}-2$ \\
4 & - & 135,0 & - \\
5 & - & 146,7 & - \\
6 & $6,91(s), 1 \mathrm{H}$ & 114,2 & $\mathrm{C}-4, \mathrm{C}-5$ \\
7 & $4,14(q), 2 \mathrm{H}$ & 56,3 & $\mathrm{C}-8$ \\
8 & $1,28(t), 3 \mathrm{H}$ & 29,6 & $\mathrm{C}-7$ \\
$5-\mathrm{OCH} 3$ & $3,93(s), 3 \mathrm{H}$ & 55,9 & $\mathrm{C}-5$ \\
$1-\mathrm{OH}$ & $8,57(s), 1 \mathrm{H}$ & - & $\mathrm{C}-2, \mathrm{C}-6$ \\
\hline
\end{tabular}

Spektrum HMBC merupakan korelasi antara sinyal proton dari $\quad{ }^{1} \mathrm{H}-\mathrm{NMR}$ dengan sinyal karbon dari ${ }^{13} \mathrm{C}-\mathrm{NMR}$ dalam dua atau tiga ikatan. Dalam hal ini hasil analisisnya dapat digunakan untuk menempatkan posisi subtituen. Korelasi sinyal proton pada pada $\delta_{\mathrm{H}} 7,45 \mathrm{ppm}(\mathrm{H}-2)$ dengan empat sinyal karbon kuarterner yaitu $\delta_{\mathrm{C}} 122,9 ; 144,4 ; 149,7$; dan 169,6 ppm. Korelasi sinyal proton $\delta_{\mathrm{H}} 6,80 \mathrm{ppm}$ (H-5) dengan tiga sinyal karbon kuarterner yaitu $\delta_{\mathrm{C}} 122,9 ; 144,4$ dan $149,7 \mathrm{ppm}$. Korelasi sinyal proton $\delta_{\mathrm{H}} 7,43 \mathrm{ppm}(\mathrm{H}-6)$ dengan dua sinyal karbon kuarterner yaitu $\delta_{\mathrm{C}} 144,4$ dan $169,6 \mathrm{ppm}$ serta satu sinyal karbon metin pada $\delta_{\mathrm{C}} 116,4 \mathrm{ppm}$. Korelasi HMBC digambarkan seperti pada

\section{Gambar 2.}

Berdasarkan data spektrum ${ }^{13} \mathrm{C}-\mathrm{NMR}$, ${ }^{1} \mathrm{H}-\mathrm{NMR}$ dan HMBC maka struktur senyawa fenolik (1) diprediksi sebagai senyawa fenol yang dikenal dengan nama 3,4-dihidroksibenzoat Analisis 1D dan 2D NMR untuk senyawa 3,4dihidroksibenzoat terdapat pada Tabel 2.

Uji aktivitas antioksidan pada ekstrak etil asetat dari kulit umbi Dioscorea hispida Dennst dilakukan dengan metode pengukuran peredaman radikal bebas
DPPH menggunakan spektrofotometer UV-Vis. Metode ini dipilih karena sederhana, cepat, mudah dan hanya memerlukan sedikit sampel (Koleva et al., 2002). Uji aktivitas tidak dilakukan terhadap isolat murni karena jumlah yang diperoleh sangat terbatas.

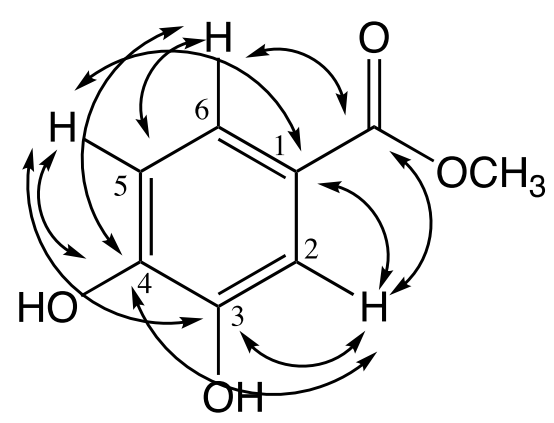

Gambar 2. Struktur senyawa metil-3-4dihidroksibenzoat hasil isolas

Hasil optimasi panjang gelombang yang dilakukan dengan menggunakan spektrofotometer UV-Vis menunjukkan bahwa serapan maksimum DPPH berada pada panjang gelombang $520,5 \mathrm{~nm}$ dengan absorbansi sebesar 1,010. Nilai absorbansi ini ditetapkan sebagai absorbansi blanko. 
Tabel 2 Data NMR senyawa metil 3,4-dihidroksibenzoat hasil isolasi dari kulit umbi Dioscorea hispida Dennst (600 MHz, MeOH)

\begin{tabular}{cccc}
\hline $\mathrm{C}$ & $\delta_{\mathrm{H}}(\mathrm{ppm})($ mult, I, $J$ dalam Hz$)$ & $\delta_{\mathrm{C}}(\mathrm{ppm})$ & $\mathrm{HMBC}$ \\
\hline 1 & - & 122,9 & - \\
2 & $7,45(d, 1 \mathrm{H}, J=2,04 \mathrm{~Hz})$ & 116,4 & $\mathrm{C}-1, \mathrm{C}-3, \mathrm{C}-4, \mathrm{C}=\mathrm{O}$ \\
3 & - & 144,4 & - \\
4 & - & 149,7 & - \\
5 & $6,80(d, 1 \mathrm{H}, J=8,22 \mathrm{~Hz})$ & 114,3 & $\mathrm{C}-1, \mathrm{C}-3, \mathrm{C}-4$ \\
6 & $7,43(d d, 1 \mathrm{H}, J=8,22$ dan $2,04 \mathrm{~Hz})$ & 122,3 & $\mathrm{C}-2, \mathrm{C}-4, \mathrm{C}=\mathrm{O}$ \\
$\mathrm{C}=\mathrm{O}$ & - & 169,6 & - \\
$-\mathrm{OCH}$ & $3,33(s, 3 \mathrm{H})$ & 47,8 & $\mathrm{C}=\mathrm{O}$ \\
\hline
\end{tabular}

Uji ini menggunakan asam askorbat sebagai kontrol positif. Asam askorbat memiliki gugus hidroksi bebas yang bertindak sebagai penangkap radikal bebas dan gugus polihidroksi yang dapat meningkatkan aktivitas antioksidan (Kim et al., 2005). Pembuatan kontrol positif dilakukan sama seperti halnya larutan sampel. Larutan sampel dibuat dengan cara melarutkan $10 \mathrm{mg}$ ekstrak etil asetat dalam $10 \mathrm{~mL}$ metanol. Kemudian larutan induk $1000 \mathrm{ppm}$ ini diencerkan menjadi 500, 250, 125, 50, 25, dan 10 ppm. Masing-masing dimasukkan kedalam vial sebanyak $500 \mu \mathrm{L}$ kemudian ditambahkan $500 \mu \mathrm{L}$ larutan buffer asetat $0,2 \mathrm{M}(\mathrm{pH}$ 5,5), $1000 \mu \mathrm{L}$ metanol, dan $500 \mu \mathrm{L}$ larutan DPPH $5 \quad x \quad 10^{-4}$ M. Campuran dihomogenkan dan diinkubasi pada ruang gelap selama 30 menit untuk selanjutnya diukur absorbansinya. Selanjutnya dihitung nilai $\mathrm{IC}_{50}$. Dari perhitungan diperoleh bahwa asam askorbat memiliki nilai $\mathrm{IC}_{50}$ sebesar 33 ppm sedangkan ekstrak etil asetat memiliki nilai $\mathrm{IC}_{50}$ sebesar $415 \mathrm{ppm}$. Aktivitas antioksidan yang dimiliki oleh asam askorbat tergolong dalam kategori sangat aktif sebagai antioksidan. Sedangkan aktivitas antioksidan yang dimiliki oleh ekstrak etil asetat dari kulit umbi Dioscorea hispida Dennst kurang aktif, namun ia masih berpotensi sebagai zat antioksidan. Hal ini sesuai dengan Molyneux (2004) yang menyatakan bahwa suatu ekstrak masih berpotensi sebagai antioksidan apabila nilai IC $_{50}$ yang diperoleh $\leq 1000$ ppm (Molyneux, 2004). Grafik perbandingan aktivitas antioksidan dari asam askorbat dan ekstrak etil asetat dapat dilihat pada Gambar 3.

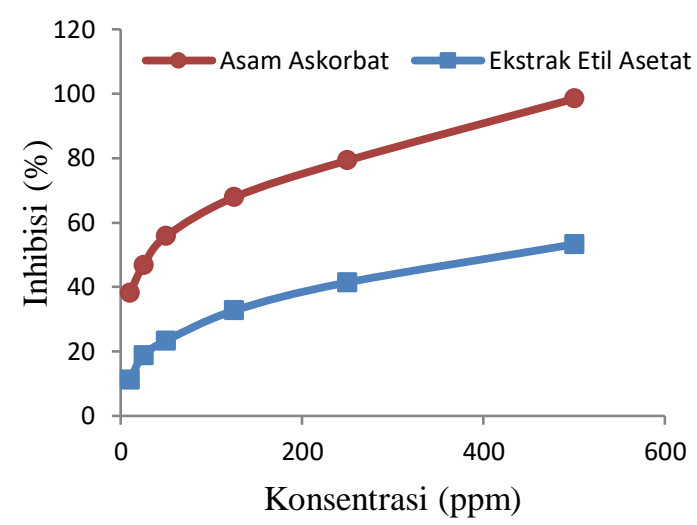

Gambar 3. Grafik aktivitas antioksidan dari asam askorbat dan ekstrak etil asetat Dioscorea hispida Dennst

\section{Kesimpulan}

Dua buah senyawa turunan fenolik berupa 4-etoksi-3-metoksifenol dan metil-3,4-dihidroksienzoat berhasil diisolasi dari kulit umbi gadung (Dioscorea hispida Dennst).

Uji aktivitas antioksidan terhadap radikal bebas DPPH dari ekstrak etil asetat kulit umbi Dioscorea hispida Dennst memperlihatkan IC 50 sebesar 415 ppm. Hal ini menunjukkan bahwa ekstrak tersebut berpotensi sebagai antioksidan. 


\section{Daftar Pustaka}

Chiu, C. S., Deng, J. S., Chang, H. Y., Chen, Y. C., Lee, M. M., Hou, W. C., et al. (2013). Antioxidant and antiinflammatory properties of Taiwanese yam (Dioscorea japonica Thunb. var. pseudojaponica (Hayata) Yamam.) and its reference compounds. Food Chemistry, 141, 1087-1096.

Itharat, A., Thongdeeying, P., \& Ruangnoo, S. (2014). Isolation and characterization of a new cytotoxic dihydrophenanthrene from Dioscorea membranacea rhizomes and its activity against five human cancer cell lines. Journal of Ethnopharmacology, 156, 130-134.

Kim, J. S. (2005). Radical scavenging capacity and antioxidant activity of the $\mathrm{E}$ vitamer fraction in rice bran. Journal of Food Science, 70, 208213.

Koleva, I. I., Beek, T. A., Linssen, J. P., Groot, A. d., \& Evstatieva, L. N. (2002). Screening of plant extract for antioxidant activity: a comparative study on three testing methods. Phytochemical Analysis, 13, 8-17.

Kothari, S., Thompson, A., Agarwal, A., \& Plessis, S. S. (2010). Free radicals: their beneficial and detrimental effect on sperm function. Indian Journal of Experimental Biology, 48, 425-435.

Middleton, E., C. Kandaswami, \& T.C. Theoharides. (1998). The effect of plant flavonoids on mammalian cells: implications for inflammation, heart disease, and cancer. Pharmacological Reviews, 52, 673751.
Min, M. A., Jiang, Z. Z., Ruan, J. L., \& Zhang, L. Y. (2011). Toxicity of a diterpene lactone isolated from Dioscorea bulbifera on hepatocytes. Chinese Journal of Natural Medicines, 9(4), 280-285.

Molyneux, P. (2004). The use of the stable free radical diphenylpicrylhydrazyl (DPPH) for estimating antioxidant activity. Songklanakarin J. Sci. Technol., 26(2), 211-219.

Noorhajati, H. (2014). Aktivitas antioksidan ekstrak kulit batang trengguli (Cassia fistula) dengan uji DPPH. Prosiding Seminar Nasional Sains dan Pendidikan Sains IX, 5(1), 467-471.

Sasikumar, J. M., Maheshu, V., Jayadev, R. (2009). In vitro antioxidant activity of methanolic extract of Berberis tinctoria Lesh. root and root bark. Journal of Herbal Medicine Toxicology, 32(3), 53-58.

Sharma, O. P., \& Bhat, T. K. (2009). DPPH antioxidant assay revisited. Food Chemistry, 113, 1202-1205.

Sunarni, T. (2005). Aktivitas Antioksidan Penangkap Radikal Bebas Beberapa Kecambah Dari Biji Tanaman Familia Papilionaceae. Jurnal Farmasi Indonesia, 2(2), 53-61.

Theerasin, S., \& Baker, A. (2009). Analysis and identification of phenolic compounds in Dioscorea hispida Dennst. Asian Journal of Food And Agro-Industry, 2(4), 547560. 